\title{
THE ROLE OF TOURISM MARKETING IN ENHANCING TOURISM DEVELOPMENT: A COMPARATIVE STUDY BETWEEN CONSTANTINE AND AMMAN CITIES
}

\author{
Foued BENGHADBANE* \\ University 'Larbi Ben M'hidi', Institute of Management of the Urban Techniques, \\ Oum El Bouaghi, Algeria, e-mail: fouad.benghadbane @ gmail.com
}

\section{Sawsan KHREIS}

Yarmouk University, Faculty of Tourism and Hotel Management, Irbid, Jordan, e-mail: sawsankhries @ yahoo.com

\begin{abstract}
Citation: Benghadbane, F., \& Khreis, S. (2019). THE ROLE OF TOURISM MARKETING IN ENHANCING TOURISM DEVELOPMENT: A COMPARATIVE STUDY BETWEEN CONSTANTINE AND AMMAN CITIES. GeoJournal of Tourism and Geosites, 24(1), 146-160. https://doi.org/10.30892/gtg.24112-349
\end{abstract}

\begin{abstract}
Tourism marketing is a key policy focus in the tourism sector development strategy of most countries in the global south. This is because of its potential as the most optimal alternative for achieving economic and social development, even in economies with daunting economic climates. In this research paper, Authors illustrates the role of tourism marketing in introducing the tourism product in the City of Constantine (Algeria) and the City of Amman (Jordan), through various methods of tourism marketing in practice, which have had a dissimilar impact on tourism revenues in both cities. The importance of the research lies in clarifying the importance of tourism marketing in achieving tourism development, as well as highlighting the tourism product as a major attraction factor for tourists. This research is based on the analytical descriptive approach in clarifying the tourism product in Constantine and Amman Cities. The research also depended on a collection of theoretical reference. The study reveals that there are wide and sharp differences in tourism marketing strategy of Constantine and Amman Cities and that there is A sharp contrast in the quality of tourism development projects of both cities, reflected by the numbers and categories of tourists coming to them.
\end{abstract}

Key words: tourism marketing, tourism product, tourism development, Constantine, Amman, Algeria, Jordan, tourism planning

\section{INTRODUCTION}

Tourism has flourished in recent years, becoming an attention-attracting industry worldwide, because of the considerable role it plays in stimulating consumption, developing trade, and promoting international communication (Qian et al., 2018). Many

\footnotetext{
* Corresponding author
} 
The Role of Tourism Marketing in Enhancing Tourism Development:

A Comparative Study Between Constantine and Amman Cities

countries of the world have, in recent decades, heavily depended on their tourism sectors for promoting economic development and have, hence taken major steps to develope it.

The World Tourism Organization reported a growth in tourism revenues as a result of increases in the number of tourists and the expansion of the global tourism market, which in 2015 achieved a growth rate of $3 \%$ per annum, accounting for about $10 \%$ of the world's net income. In addition, in 2014, the number of tourists worldwide reached 1.13 billion tourists, marking an increase of 51 million tourists compared to 2013. Tourism has also provided 260 million job opportunities globally, representing around $11 \%$ of total jobs worldwide (WTO, 2016). With the exception of the increased number of natural disasters, tourism will become the largest industry in the world. This is an increasingly important motive for globalization in terms of intensive cross-border economic, social and cultural relations. Alongside that increase, individual countries are trying to attract potential tourists to earn tourism-related gains (Arasli, 2014). Consequently, tourism marketing constitutes a key factor in achieving tourism development due to its role in promoting tourism and providing services. Therefore, tourism marketing through publicity and advertising has become a necessity for attracting tourists and create the motives of consumption of the tourism product and expand the tourist market. The studies relating to the extent of the popularity of tourism products are of no less importance in the field of tourism marketing (Benhaddou, 2017). It is worth mentioning that adopting a successful marketing approach is expected to create uninterrupted communication between the tourism industry and its consumers. This requires a comprehensive national plan for tourism marketing, in addition to the individual efforts made at the level of touristic and hotel companies. The joint efforts at the governmental and community levels, especially during events such as festivals, conferences and others, play an important role in promoting the tourism product as well. In sum, tourism marketing helps introduce the tourism product and provide the suitable conditions for attracting tourists and creating spending opportunities to raise the volume of revenues and expand investments, which will have a direct impact on activating the tourism development movement.

\section{RESEARCH PROBLEM}

In the context of global economic changes, many countries have prioritize the tourism industry especially Arab countries that have found in the development and improvement of tourism sector an appropriate alternative to compensate their losses in other economic sectors through its financial revenues, or a strategic option to build an economic base with its revenues amidst the limited resources (Benghadbane, 2013).

In this respect, Algeria stands out as an example of the former case, Algeria seek new opportunities to diversify its economic offers. Tourism is considered one of the sectors that deserve attention and giving priority (Boumendjel, 2010). However, with the stability in security that Algeria witnessed, coupled with the adoption of a balanced and coherent strategic planning, they can ensure a sustainable growth of tourism.

On the other hand, the second case is represented by Jordan; a country with limited natural resources, which depends on the tourism sector (which represent $13 \%$ of GDP) to develop its economy (Abuamoud et al., 2014). The tourism sector in Jordan has seem significant improvements (Sullivan, 1999) with the Jordanian government undertaking several initiatives in recent years . The tourism sector in Jordan has seem significant improvements (Sullivan, 1999) with the Jordanian government undertaking several initiatives in recent years (Al-Akra et al., 2010). In both cases of Jordan and Algeria, it is necessary to follow a tourism marketing strategy to bring about change for the better through adopting organized and effective promotional plans to achieve the 
desired tourism development. In this research, we shed light on the City of Constantine in Algeria and the City of Amman in Jordan, which are living this situation and tourism marketing played in them a vital role in identifying the tourism product and achieving different levels of tourism development regardless of size and degree of marketing efforts. Hence the problem of this research emerges, which is centered on this question:

What is the role of tourism marketing in enhance tourism development in the cities of Constantine (Algeria) and Amman (Jordan)?

\section{RESEARCH PURPOSES}

The aim of the research is to identify the role of tourism marketing in enhancing tourism development in Constantine and Amman Cities as tourist destinations, along with clarifying the existing variation in the use of tourism marketing methods and tools. This Study aims at providing recommedations to decision makers to improve marketing methods.

\section{RESEARCH IMPORTANCE}

The importance of the research lies in clarifying the importance of tourism marketing in enhancing tourism development, as well as identifying the most appropriate tourism marketing methods and ways as a key factor in expanding tourism investment opportunities and raising its revenues, along with highlighting the role of stakeholders working in the field of tourism in the process of marketing.

\section{RESEARCH METHODOLOGY}

This research is based on the analytical descriptive approach in clarifying the tourism product in Constantine and Amman Cities, and how to clarify the role of tourism marketing in promoting tourism development projects, in addition to the comparative approach, which is concerned with clarifying the various discrepancies existing in the use of ways and methods of tourism promotion to highlight the level of tourism development achieved in Constantine and Amman Cities. It is noticeable that despite the difference geographical locations of the two cities, as the former is located in Africa and the latter is in Asia, they have a resemblance in their specific location. Despite the geographic difference between the city of Constantine and the city of Amman, both have a long inveterate history. The research also depended on a collection of theoretical references from books, magazines, articles and documents that allowed to identify the tourism product in the two cities and the completed and programmed tourist projects and the importance of practicing tourism marketing in developing them.

\section{GEOGRAPHICAL CHARACTERISTICS MOTIVATING TOURISM DEVELOPMENT}

The city of Constantine is located in the east of Algeria at a latitude of $36.23^{\circ} \mathrm{N}$ and a longitude of $7.35^{\circ} \mathrm{E}$, thus occupying a distinct region with suitable topography (Larouk, 1984), within the hill atlas between the coastline and the northern border of the desert, as it is $245 \mathrm{~km}$ far from the Algerian-Tunisian eastern borders, $431 \mathrm{~km}$ from Algiers in the west, $235 \mathrm{~km}$ from the town of Biskra in the south, and $89 \mathrm{~km}$ from the town of Skikda in the north. The strategic location allowed it to play an important role in the Algerian East, which it mediates geographically through historical functional relations, which increased the importance of the city on the economic, social, cultural and political levels as the meeting point of all land and air transport, and an industrial economic center at the national level, especially in the mechanical industries. Constantine has a population of 418,672 in 2008, which makes it the third rank in the ranking of Algerian cities after 
The Role of Tourism Marketing in Enhancing Tourism Development:

A Comparative Study Between Constantine and Amman Cities

Algiers and Oran (ONS, 2011). The city of Amman is located in the north-west of the Hashemite Kingdom of Jordan, between the intersection of the latitudes of $31.25^{\circ}$ and $32.1^{\circ} \mathrm{N}$ with longitudes of $35.66^{\circ}$ and $36.42^{\circ} \mathrm{E}$ (Khawaldah, 2016) (Figure 1). This location allowed it, thanks to its various features, to be a city representing a capital, through its connection to all regions of the Kingdom, as it has a strategic location with easy access. The size of the city of Amman according to the last general census of the population and housing for the year 2015 is 4.007 .526 people, with indication that this size covers all the Greater Amman Municipality (Hashemite Kingdom of Jordan, 2016), which represents $42.04 \%$ of Jordan's total population. This means that nearly half of the Kingdom's population is concentrated in the Greater Amman Municipality (but by less than eight degrees percentage), making it stand on the top of the Jordanian urban system.

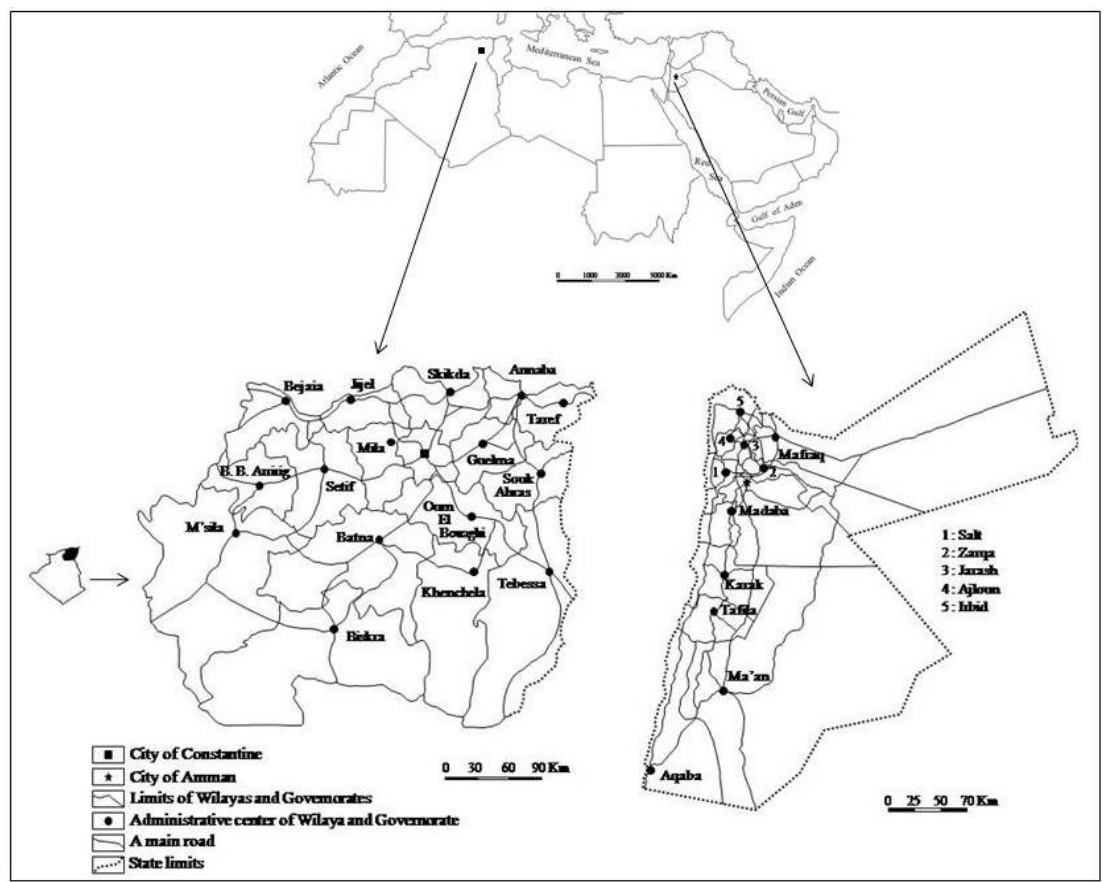

Figure 1. Administrative location of Constantine and Amman cities (Source: Michelin, Carte routière et touristique: Algérie- Jordanie, 1/10.000, Michelin édition des voyages, Paris, 2003)

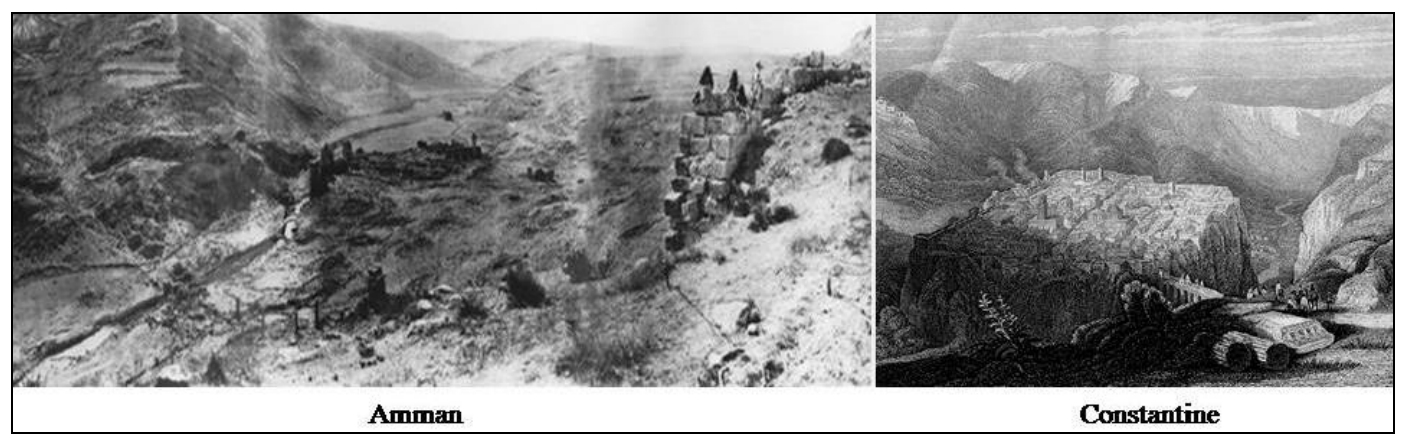

Figure 2. The original location of the cities of Constantine and Amman in its infancy stage (Source: Archives of Constantine Municipality, Greater Amman Municipality, 2014) 
It is noticeable that despite the difference geographical locations of the two cities, as the former is located in Africa and the latter is in Asia, they have a resemblance in their specific location. Both cities are internal cities within a mountainous spot. The location of Constantine is composed of a group of mountains that are high and a number of surrounding hills. The location of the Constantine city is divided into Rhumel Valley and Boumerzoug Valley. A mountainous nature also dominates the location of the Amman city and which was called "city of seven mountains", in relation to the first seven mountains that make up this location (Figure 2). All these available elements make the two cities a fertile place for multiple tourist products that require proper planning to market them to achieve tourism development in both cities.

\section{DIFFERENT TYPES OF CLIMATE FOR VARYING TOURISM ACTIVITIES}

The city of Constantine is dominated by the warm Mediterranean climate in summer and the cold in winter (Benghadbane, 2001). The city of Amman has a Mediterranean climate, especially on the western highlands of the region, while some of its areas in the eastern part cover the semi-desert climate (Potter et al., 2009) (Table 1). These climatatic characteristics affect tourism activities negatively in that climate shortens tourism season.

Table 1. Some climatic characteristics in the both cities of Constantine (Algeria) and Amman (Jordan) (Data source: Aeronautical Observatory in Ain El Bey-Constantine, 2016 and DOS in Jordan, 2016)

\begin{tabular}{|c|l|c|c|}
\hline \multicolumn{2}{|c|}{ Elements of Climate } & Constantine (Algeria) & Amman (Jordan) \\
\hline \multirow{2}{*}{$\begin{array}{c}\text { Temperature } \\
\left({ }^{\circ} \mathrm{C}\right)\end{array}$} & Annual rate & 15,40 & 25.8 \\
\cline { 2 - 4 } & Minimum (winter) & 9,19 & 13 \\
\cline { 2 - 4 } & Maximum grade (summer) & 41,00 & 32 \\
\hline $\begin{array}{c}\text { Quantity of } \\
\text { precipitation } \\
\text { (Mm /yr) }\end{array}$ & Annual average & 512 & 259,8 \\
\cline { 2 - 4 } & Minimum Quantity (Summer) & 8 & 0 \\
\cline { 2 - 4 } & Maximum quantity (winter) & 71 & 61 \\
\hline
\end{tabular}

\section{IMPORTANT HISTORICAL LEGACY PROMOTING THE TOURISM PRODUCT}

Despite the geographic difference between the city of Constantine and the city of Amman, both have a long inveterate history, reflecting the successive civilizations that have remained largely untouched, which is now an important tourism product that needs to be reintroduced and marketed through important promotional plans to attract tourists. The rock (Le Rocher) is the most important topographic unit: the first nucleus of the city of Constantine, with an area of 40 hectares. It is surrounded by natural obstacles (sand dunes and steep slopes), from all directions except the western side where it is naturally connected to a $300 \mathrm{~m}$ bar (Figure 3). The history of the city of Constantine dates back to 1450 years BC. It was the capital of the Kingdom of Nomidia for 157 years.

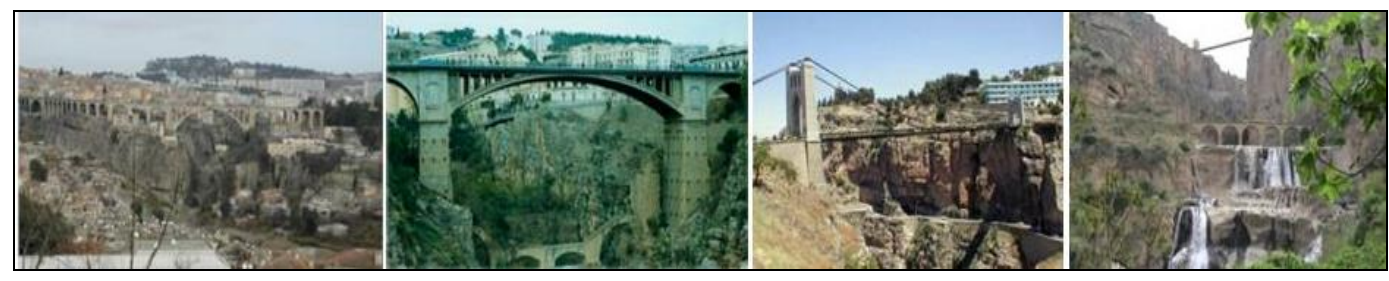

Figure 3. Qantara Bridge, Sidi Rashed Bridge, Sidi M'sid Bridge,

Al Shalalat Bridge in Constantine city (Source: Archives of Constantine Municipality, 2001) 
The Role of Tourism Marketing in Enhancing Tourism Development:

A Comparative Study Between Constantine and Amman Cities

It was known as the "Cirta" (Boucharab, 2006). The city of Constantine turned into Islam after seventy (70) years of attempted Arab Islamic Invasion of the region of Maghreb (Benidir, 2007). After the French colonization and the fall of the city in 1837 after violent resistance from the residents, the city became divided into two sections, a special section for French and Jews and a section of the Algerian Muslim population (Régis, 1880). Following its independence, the city of Constantine became increasingly urbanized as a result of inflow of migrants from neighboring (Nait-Amar, 2015). The city of Amman dates back to more than 5000 years BC. During this long period of human history, the city has witnessed many ancient civilizations that have left their mark on their location, the marks that were uncovered by excavations in many areas of the city, as the first human presence in the city was on the eastern side, specifically in the region of "Ain Ghazal" (Bakij, 2002).

On May 25, 1946, the country became independent and the Emirate became a kingdom. The city of Amman was declared as the capital of the Hashemite Kingdom of Jordan. The importance of the city as a development pole for the Kingdom has increased, as all planning policies in the Hashemite era have applied the concept of "center and periphery" as a regional development method that examines the relationship between the capital and its urban edge located within its territory on the one hand, and between its territory and the developing regions of the Kingdom on the other hand (Al-Asad, 1997).

\section{ESSENTIAL AND DIVERSE INFRASTRUCTURE THAT SUPPORTS THE MARKETING OF TOURISM PRODUCT}

The infrastructure includes all the services supporting tourism development.

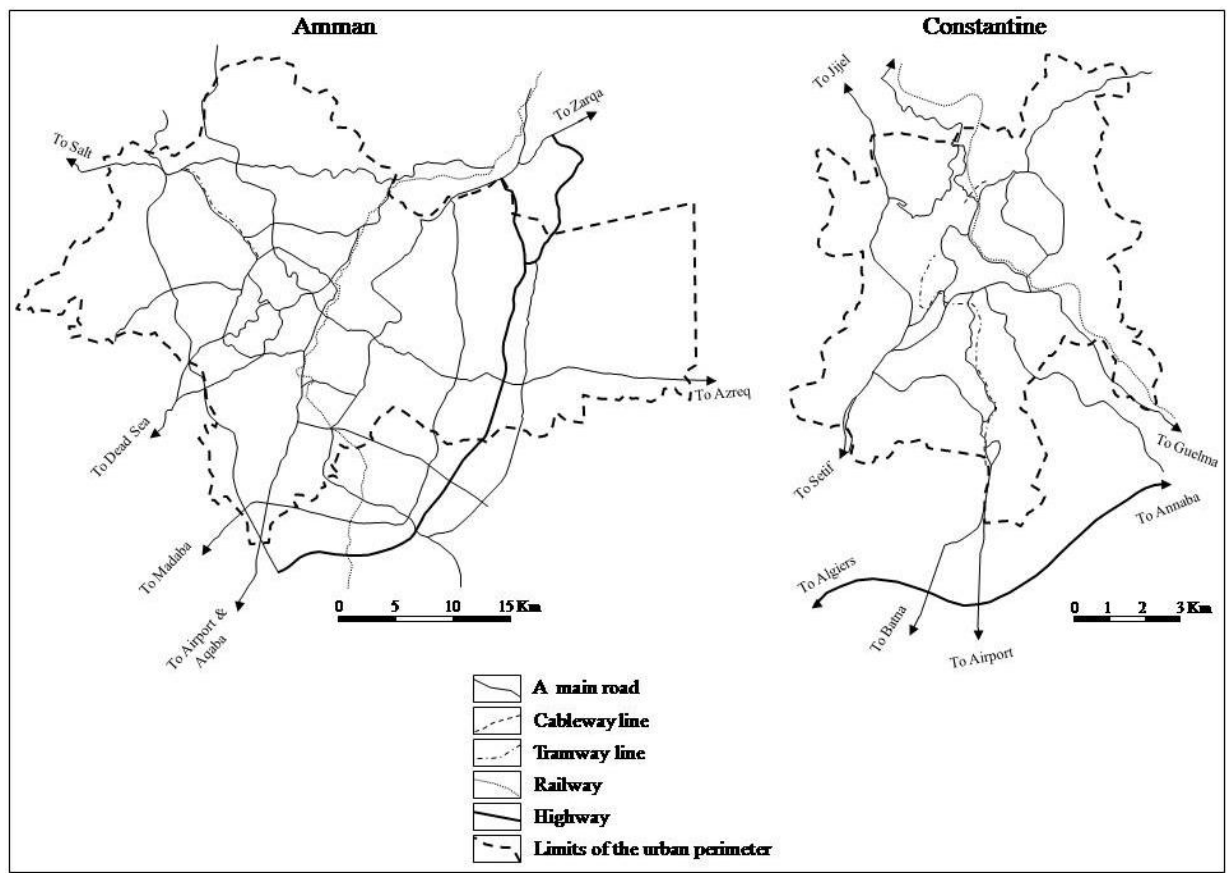

Figure 4. Transport infrastructure in Constantine and Amman cities (Source: URBACO-EDR, Schéma de cohérence urbaine de Constantine, Mission II, URBACO, 2007, p. 62, Map of Amman city : www.visitjordan.com)

The most important of these are the highways, railways and airports, which have a large share in both cities, and which facilitate the movement of tourists from one area to 
another to explore the various sites, especially by providing public transportation of all types (Boukerzaza, 2015). Furthermore, the communications network in both cities is good enough to meet the needs of tourists (Benghadbane, 2001; Dayafla, 2014) (Figure 4).

Furthermore, health services are intensively and efficiently provided for visitors, whether local residents or tourists, especially for emergency cases, as the two cities have many governmental and private hospitals (Belbacha, 2011; Zyoud, 2016).

Among the most important infrastructures that serve tourists in the first place are the accommodation structures. In this regard, both Constantine and Amman Cities have a number of graded and ungraded hotels with various capacities allowing tourists to be accommodated according to their socio-professional categories. However, the number of hotels in Amman is very high compared with the city of Constantine, which has a direct impact on the number of the incoming tourists, as well as the quality of the services and the job positions provided (Bader et al., 2016) (Table 2).

Table 2. Distribution of hotels in Constantine (Algeria) and Amman (Jordan) (Data source: Directorate of Tourism and Traditional Industries of Constantine, 2016 + DOS in Jordan 2016)

\begin{tabular}{|l|c|c|}
\hline \multicolumn{1}{|c|}{ Hotels } & Constantine (Algeria) & Amman (Jordan) \\
\hline Number of hotels & 23 & 452 \\
\hline Number of categorized hotels & 14 & 239 \\
\hline Number of uncategorized hotels & 09 & 303 \\
\hline Total number of beds & 2.437 & Data are not available \\
\hline Job positions provided & 966 & Data are not available \\
\hline
\end{tabular}

\section{TOURISM DEVELOPMENT PLANNING VIS À EFFECTIVENESS OF TOURISM MARKETING}

A development strategy has been adopted based on the marketing method of the tourist product in both cities in a different style according to the prevailing economic trends in each city, enhanced by the completion of a number of tourism projects, which had a clear impact in raising the level of quality of tourism services. The most important ones are:

\section{Important projects based on tourism product :}

The strategy of tourism development in Constantine and Amman Cities was based on the enhancement of tourism product through a number of tourism projects in response to the expected number of tourists. In the city of Constantine, many major urban touristic projects have been carried out, including:

- Projects aimed at increasing the capacity of tourist accommodation through building Marriott Hotel on the northern edge of "Ain El Bey" plateau (Figure 5). The hotel is a branch of the international American hotel chain (Hecham-Zehioua, 2010).

- The Grand Exhibition Hall "Ahmed Bey" is located in the southern part of the city of Constantine (Figure 6). The Hall hosts all national and international cultural events, as well as the city's theaters and opera (Zaidi, 2013).

\section{Structural projects related to the easy access of tourists:}

- The Tramway Project, completed in 2013 , has a capacity of 6,000 passengers / hour, which extends for a length of $8 \mathrm{~km}$ between Constantine city center and its southern destination. Currently, the project extends south to the new city of Ali Mendjeli passing through the international airport and the university city (Hecham-Zehioua \& Labii, 2009).

- The aerial tramway project was completed in 2008, connects the city center with its eastern neighborhoods. It passes through the sand heights, reaching the neighborhoods of Emir Abdelkader and TatashBelkasem. The tourist can identify the 
The Role of Tourism Marketing in Enhancing Tourism Development:

A Comparative Study Between Constantine and Amman Cities

different tourism potential of the city from the top; The tramway is equipped with 33 passenger cabins with a capacity of 1200 passenger/ hour in one direction (Rebai, 2010). This line is expected to be extended to Djebel El Wahch in the north-eastern part of the city where the Mosta - land is located.

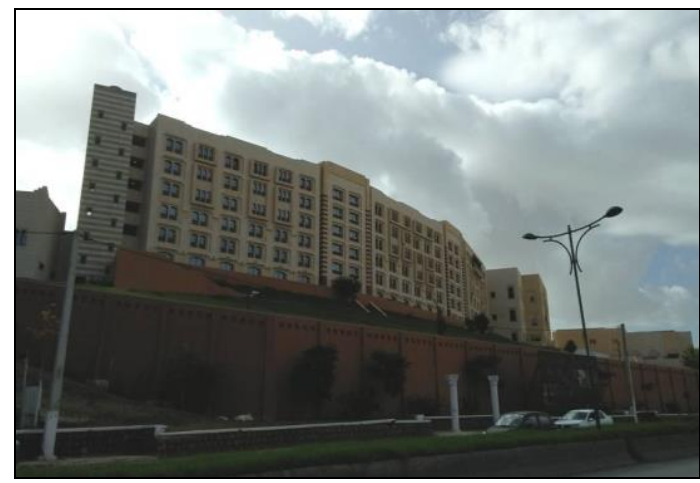

Figure 5. 'Marriott' Hotel in the City of Constantine

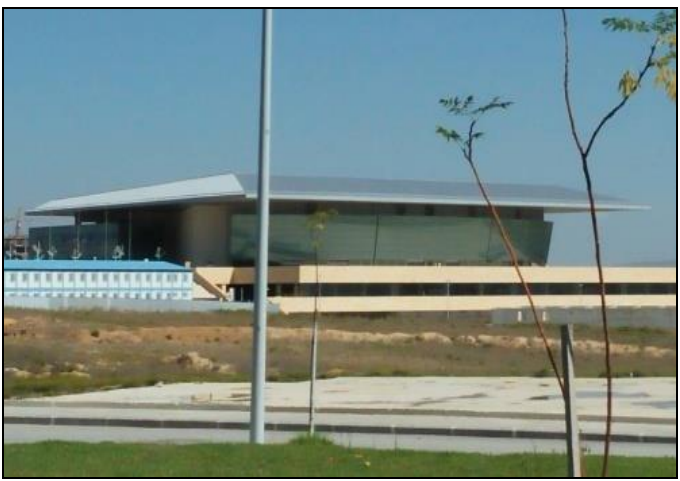

Figure 6. Grand Exhibition Hall

'Ahmed Bey' in the City of Constantine

- Pont Geant Salah Bey Project: Completed by the end of 2013, it connects the United Nations Plaza (the beautiful scenery hill) in Mansoura town (Mansoura Plateau). It passes over the Oued Rhumel with a length of 4,300 meters, with double passageways, one for pedestrians and the other for vehicles (Boudjadja, 2014) (Figure 7).

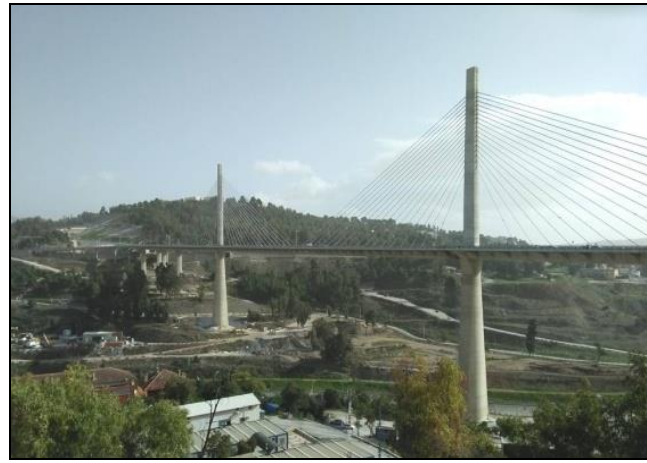

Figure 7. Pont Geant 'Salah Bey' in the city of Constantine

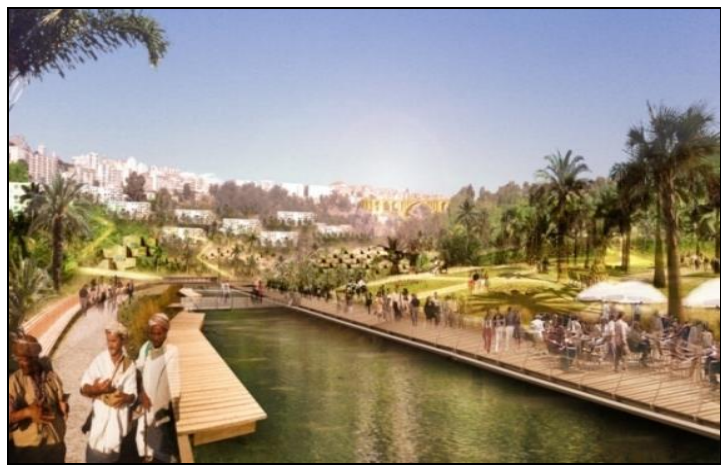

Figure 8. Preparation of the district 'Bardo' in the city of Constantine (Source: Boudjadja, 2014, p. 37)

- Reinforcing and renovating the existing cultural and religious structures and facilities in the city to ensure their cultural role in tourism development. In particular, the rehabilitation of Dar El Thakafa "Mohammed Al Eid Al Khalifa" and converted to the Palace of Culture, and the same thing to the Dar El Thakafa of " Malik Haddad " beside the rehabilitation of the Wali in the Casbah district and turn it into a center for the arts, rehabilitation and equipping "Bey Palace " and the regional theater, and the equipping of Emir Abdelkader Mosque (Rebai, 2010).

- Restructuring of the city center of Constantine, a process of urban intervention carried out by the participation of merchants, inhabitants and local authorities, aimed at rehabilitation of the fabric of the old city and exit buildings along the main axes in 
order to improve the tourism form of city center of (Boufenara, 2008) it was specified 19 Joan Street, Awati Mustafa Street and Blozdad Street, in addition to the preparation of public squares (Hecham-Zehioua, 2010).

- The removal of anarchic housing in Bardo district estimated at 2000 homes during the period 2008-2010 on an area of 115 hectares and the expulsion of 5700 inhabitants to the new city "Ali Mendjeli" In order to recover a strategic property adjacent to the city center to program important projects, on the one hand, and on the other hand to improve the urban landscape (Milous, 2006) to suit the desired tourism development strategy.

- The preparation of the district "Bardo", by programming many tourism investment projects on part of the property recovered after the destruction of anarchic housing, and the establishment of an entertainment and amusement park on an area of 65 hectares (Figure 8), By preparation of the sides of Oued Rhumel and by completing ecological, commercial and environmental facilities and structures (Boudjadja, 2014).

- The establishment of a university city named "Constantine 3 Saleh Boubnider university" on an area of 170 hectares of the aims of strengthening the role of the university in economic and social level, and it represents continuity of the city of Constantine as a city of science and scientists since the establishment of Association of Muslim Algerian Ulema led by "Abdul Hamid bin Badis".

\section{Future Projects Include}

- The establishment of a village for the traditional industry in Bardo District in the field of industry of copper pots and copper engraving, because Constantine was known throughout the ages of copper and its traditional industry, so it was necessary to preserve the handicraft character of the region and promote it with traditional industries, especially the gold industry and jewelry (Zaidi, 2013), In addition to the project of preparing the underground tunnel adjacent to the Culture Palace "Mohammed Al-Eid AlKhalifa" in the city center, by allocating shops to display and sell traditional handicrafts and industries and to create jobs.

- Preparation of the "tourist trail" located at the bottom of the sand along the rock, Starting from the Roman baths located under the bridge " Sidi Rached Viaduct" and the passing under the bridge "Qantara", down to the bridge "waterfalls" with a distance up to $1800 \mathrm{~m}$, width of $1.5 \mathrm{~m}$ and a height of $150 \mathrm{~m}$.

- Completion of 03 areas for tourism expansion in: Djebel El Wahch, Shattabah and El Meridj, including many tourism and leisure projects (Belbacha, 2011).

In addition to these projects, the city of Constantine includes several tourism destinations; perhaps the most important can be mentioned: The old city of Suweika, Many museums (Cirta, Mujahid), Bridges, Ahmed Bey Palace, EmirAbdelkader Mosque, Many of Dar El Thakafa, theaters and festivals (music, roses).

For the city of Amman with its unique and its proximity to the Dead Sea and AlMaghtas and its archaeological cities of Umm Qaïs and Jerash in the north and the city of Madaba in the south, beside it is a political and economic capital of Jordan (Orieqat, Saymeh, 2015), Which has gained increasing importance of the central authorities to support it with tourism projects, as follows:

- Creation Project of Raghdan Tourist Complex: The Raghdan tourist complex is one of the historical and archaeological monuments that characterize city center.

- Abdali Project: The city of Amman represents a fertile ground for the completion of various investment projects, especially real estate, the adequate stable political and security conditions the and the availability of information and communication technology, the potential of investment extends to the completion of business offices and luxury hotels and luxury residential neighborhoods (Aljafari, 2014), The Abdali project 
The Role of Tourism Marketing in Enhancing Tourism Development:

A Comparative Study Between Constantine and Amman Cities

comes as a pilot project to develop the city center and redevelop urban areas with multiple uses, and the collection of local and international investments in an environment conducive to the business center and the capital center (Figure 9).

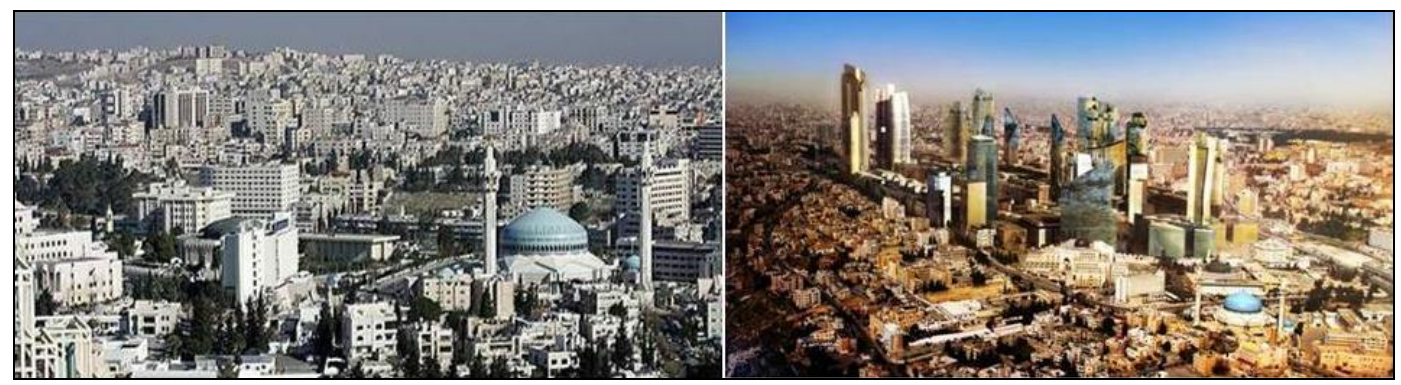

Figure 9. Abdali Region before and after the project execution in Amman City (Source: Aljafari, 2014)

The built-up area is 1.7 million square meters,, it includes office towers, luxury hotels, leisure facilities, high residential areas, recreational and cultural facilities, government buildings and a transport center, as well as a national museum and two elegant hotels. The 55 hectares of land adjacent to the project will be consumed. Upon completion, the project is expected to house 40,000 inhabitants, 15,000 jobs, 25,000 car parking, The project is supposed to consist of 70 High towers with a height of about 220 m (Beauregard et al., 2011). Abdali has been developed as a smart center for the city, combining media and communication infrastructure to ensure that the most advanced technologies are delivered to all homes, offices, shops, It also has general energy solutions and central gas systems to provide a sound and clean environment, as well as a significant savings in the energy bill, The project will be fully equipped with technically sophisticated systems for building management, fire protection, safety management and precautionary measures. The Abdali development will contribute to get effective traffic solutions around and within the project, ensuring the flow of 90,000 people / day of the inhabitants, employees and visitors when the project is fully operational.

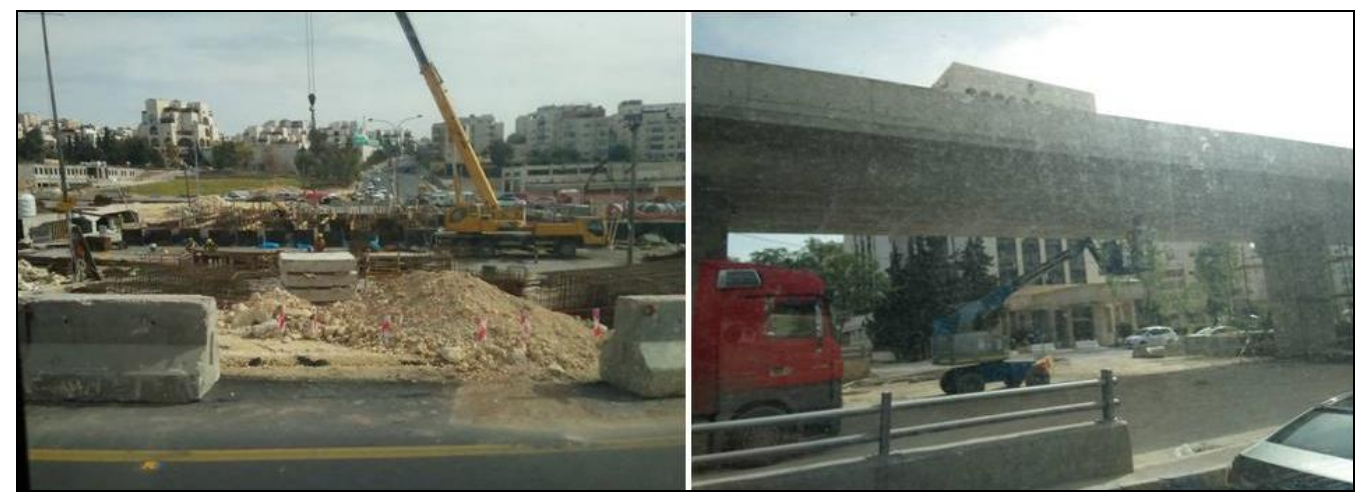

Figure 10. First Track of Execution Project of Tramway in "Princess Ranya Al Abdulla" in Amman City

- Rapid Bus Project (Tramway): The strategy of the "Rapid Bus" project is illustrated by the Greater Amman Municipality plan to improve public transport services in the capital, Which aims to provide a quick, safe, and convenient transport service with priority at a reasonable cost, taking advantage of current and future infrastructure, and 
based on balancing between the priorities, so that the project is compatible with internal and external traffic patterns and the implementation of traffic improvements to achieve a gradual shift in the structure of current services (Pinel, 2013).

The rapid bus project includes three tracks. The first is to connect "Sweileh" to the "station" at a distance of $16 \mathrm{~km}$, and the second connects the sports city and the Ras AlAyn district at a distance of $90 \mathrm{~km}$, and the third connects the station and As Sakhrah Al Musharrafah in the south at a distance of $7 \mathrm{~km}$, Where it is connected with the Al-Wehdat area in Ash-Sharq Al-Awsat Interchange, and is currently underway to complete the first track of this project (Figure 10).

- Tourism projects that promote social integration and communication between the different groups in society: At the level of the Greater Amman Municipality, many urban projects (Daher, 2008) enable them to enjoy the panoramic views of the city without payment of fees (a sum of money). These projects include creating the "Rainbow" street in Jabal Amman in 2005 and "Agencies" street in Sweifieh district. The Hussein Cultural Center, formerly a playground for children living in Jabal Amman and Jabal Nazif, was also established (Ababsa, 2011). In 2005, an open theater was opened on the slopes of Jabal Amman serving as a bridge between the east and west of the city and welcoming all social groups in the eastern part of the city (Ababsa, 2007).

- Tourism projects to preserve the heritage: Many urban projects have emerged that aim to promote urban renewal in some spaces through urban and architectural interventions in the context of preserving the urban heritage of the city and to emphasis on identity and belonging, including: "Gara" market and "Rainbow" street, Jabal Amman, enabling all local people and different associations to promote and sell their traditional products. (Ababsa, 2011).

Therefore, these tourism projects are of great importance in attracting tourists and lengthening the duration of their stay. This requires a solid plan of marketing in both cities .

\section{TOURISM MARKETING AN ESSENTIAL PILLAR OF TOURISM DEVELOPMENT PLANNING}

Tourism marketing methods and promotional plans vary between Constantine and Amman Cities; this have a direct impact on the level of tourism development achieved in both cities, which is illustrated below:

\section{Tourism Marketing connected to the minds of dealers with modest initiatives with multiple obstacles in the city of Constantine}

The city of Constantine has received great attention from the central authorities since independence (1962), especially after receiving a large migration from the interior areas, by signing several residential projects, providing jobs by expanding the industrial zone inherited from the colonial era " Palma Lamouriciere", (Benghadbane, 2011) and establishing another industrial zone "Boumerzoug" as well as the industrial complex for the mechanical industries of agricultural equipment in the valley of Hammim. However , tourism sector was marginalized; the share of tourism projects was not more than $2.55 \%$ of the total projects (Tessa, 1993).

In spite of the promotional plans adopted by the National Tourism Bureau to market the Algerian tourism product in the period 2007-2015 locally and internationally to increase the number of tourist arrivals using many methods to introduce the Algerian tourist product, these plans remained limited due to many obstacles such as the minds of the dealers of the tourism sector and many other problems. The statistics indicate that the tourist movement in Constantine is characterized by fluctuation and decline.. It is worth mentioning that since the selection of the city of Constantine as the capital of Arab culture 
The Role of Tourism Marketing in Enhancing Tourism Development:

A Comparative Study Between Constantine and Amman Cities

in 2015, the city has seen an acceptable increase in the number of tourists, which amounted to 169.609 tourists, including 28,472 foreign tourists (16.78\%); however, this increase was not commensurate with the size of the cultural event in Constantine.

Despite the presence of many stakeholders in the field of tourism, but their role was very limited in marketing the tourist product of the city of Constantine.

Major stakeholders include the following:

- Directorate of Tourism and Traditional Industries of the State of Constantine: which is one of the external interests of the Ministry of Tourism?

- The Algerian National Bureau of Tourism: which monitors the bodies that practice tourist activity, collects data related to tourists and participates in tourism events in order to develop tourism product?

- The Municipal Office for Tourism: It prepares programs promoting the tourism in the medium and long term and ensures their implementation.

- Directorate of Culture of the State of Constantine, which is keen to protect the urban and cultural heritage and historical monuments and follows up its restoration and rehabilitation.

- Travel agencies and tourism: the number of which is 35 tourist agencies, including 05 government agencies and 30 private agencies; it organizes trips individually and collectively inside the city of Constantine to visit sites and monuments and to organize Hajj and Umrah trips outside Algeria.

- Tourist associations: There are many associations in the city of Constantine, amounted to 104 associations, most of them are concerned with preserving the musical heritage of the city, "Malouf music", and urban heritage especially the buildings of the old city (Directorate of tourism and crafts of the Wilaya of Constantine, 2016); this made tourism marketing not prioritized by these bodies and actors in the field of tourism activity of the city of Constantine.

International tourism marketing based on the experience and voluntary will to achieve sustainable growth in the city of Amman

The current tourism marketing plan in Amman is based on the principle of "Sustainable Tourism for Development", drawing on local and regional experiences and expertise to achieve the best practices in the development of tourism and sustainability in the city within the framework of the global trends for the sustainable development of the prospects of 2030. The city of Amman is increasingly growing as a result of the high rates of urbanization which have had repercussions on the lifestyle of the city and tourism on the one hand, at the same time; the city is growing in the travel and tourism sector compared to the rest of the other economic sectors on the other hand. The marketing plan ensures that the competition between urbanization and tourism is compatible with sustainable growth, taking into consideration the needs of the local population, businessmen and tourists, so that this plan is purely tourist oriented to develop the city and its prosperity, competitive with tourism and includes strong marketing programs to attract the largest number of tourists in the Middle East. The marketing plan engages various actors in the tourism sector of the city, especially the Ministry of Tourism and Antiquities, the Greater Amman Municipality, the Tourism Promotion Authority, the World Tourism Organization and all investors from the public and private sectors, national associations and tourism companies. All participants adhered to the Global Code of Ethics for Tourism aiming to achieve tourism development for making sustainability of cities and tourist destinations. This plan calls for commitment to common social responsibility towards human and society in planning and practicing tourism activities to achieve responsible, sustainable and accessible tourism for all social groups (Bader et al., 2016). 


\section{RESEARCH RESULTS}

The analytical study revealed that there are clear differences in methods of tourism marketing, reflected in the level of tourism development achieved through and projects. Despite the difference in geographical location and the convergence in the types of tourism products (natural, historical, urban, cultural), they are Arab cities similar in characteristics of their location.

- There is a sharp contrast in the quality of tourism development projects of both cities, reflected by the numbers and categories of tourists.

- The completion of tourism projects of Amman was subjected to specific plans to ensure the following-up and handing the projects over in the horizons set for them by facilitating procedures and granting incentives, while in the case of Constantine, most tourist projects was delayed and others have not yet started due to a number of obstacles related to tourist property, inadequate funding in areas of tourism expansion, village of traditional industries and many hotels ...

- Tourist marketing in Amman was represented by intensive participation in world fairs of tourism, e-marketing, updating the Jordan Tourism board website to include almost all languages of target tourists,promotion of new products, intensive efforts to promote niche markets for potential tourists. However, tourism marketing in Constantine targeted only the local, national and even regional levels.

- There are many factors that contributed to the success of promotion of tourism in the city of Amman, while tourism marketing in Constantine encountered many obstacles, perhaps the most important of which are the mentality of various stakeholders and the lack of training in hotel industry and tourist services, which had a direct impact on quality of tourism services.

Finally, the study concluded that the development of a tourism marketing strategy requires an accurate information system, enabling market research studies in of Amman. In Constantine, this information system is characterized by the inadequacy of data making it difficult to develop market research studies.

\section{RESEARCH RECOMMENDATIONS}

In the light of the previous results, some recommendations that would enable the effective and strict implementation of the tourism marketing strategy in Constantine are included to achieve the desired tourism development on the one hand, and upgrading the city of Amman as a world tourist city on the other hand, the most important of which are described below:

- The need to adopt a strategy for marketing of tourism in Constantine to achieve the tourism development envisaged taking into account all clients and partners as a voluntary process.

- Developing renewed plans for tourism promotion in the city of Constantine, to adapt to the available financial resources, to take into account the requirements of the tourist market at different spatial levels starting from local (domestic) marketing before the international, and to take into consideration the body and category to be targeted.

- Promoting the culture of tourism and tourism awareness among the various actors, especially the inhabitants of Constantine, and encourage them to participate in the tourism promotion plans as they are community that can develop traditional industries that contribute directly to tourism development.

- Taking care of infrastructure and tourism services, and providing various facilities for tourists because of its importance in attracting tourists.

- Providing various investment incentives in the city of Constantine to integrate the 
The Role of Tourism Marketing in Enhancing Tourism Development:

A Comparative Study Between Constantine and Amman Cities

private sector as a key partner in tourism development, especially fees and taxes, and banking facilities ... in order to speed up the completion of various tourism projects.

- Benefiting from the experience of the city of Amman in a rational manner in conformity with the specificity of the Algerian tourism market.

Maintaining tourism marketing in the city of Amman and promoting digital tourism in it and upgrading it to be an international tourist city.

It is obvious from the above that there is a need to develop a strong and effective tourism marketing system preparing the individual to be engaged with the tourism activity through tourism awareness and culture, which can be carried out only with the tourism voluntary will of the state to facilitate the tourism movement and contribute to marketing studies through its support to various stakeholders of tourism activity.

\section{CONCLUSION}

This study stresses the importance of tourism marketing in achieving tourism development in Constantine and Amman Cities. Despite the fact that the tourism products of the both cities are similar, that of Constantine is superior in terms of its tourism potential, although the city of Amman has made great strides in its tourism development through various tourism projects, the city of Constantine is seeking to adopt a strategy of tourism marketing as decision maker are convinced that it has a great role in developing tourism which was marginalized. This strategy should be included in the tourism development guideline.

\section{REFERENCES}

Al-Akra, M., Eddie, I. A., \& Ali, M. J. (2010). The association between privatisation and voluntary disclosure: Evidence from Jordan. Accounting and Business Research, 40, 1, p. 55-57.

Al-Asad, M. (1997). Old Houses of Jordan: Amman 1920-1950. TURAB, Amman, p. 197.

Ababsa, M. (2011). Citizenship and Urban Issues in Jordan. Cities, Urban Practices and Nation Building in Jordan. Presses de l'Institut français du Proche-Orient, p.39-64.

Ababsa, M. (2007). Amman: stone and peace, Collection "Cities in movement", Autrement, Paris, p. 295.

Abuamoud, I.-N., Libbin, J., Green, J. \& ALRousan R., (2014). Factors affecting the willingness of tourists to visit cultural heritage sites in Jordan. Journal of Heritage Tourism, 9, 2, p. 148-165.

Ahraw, W. (2013). Urban Heritage: A Tool for Activating Sustainable Tourism, Case of Greater Constantine. Thesis of Magister, University of Oum El Bouaghi, Algeria, p. 186.

Aljafari, M. (2014). Emerging public spaces in the city of Amman, Jordan: An Analysis of Everyday Life Practices. Thesis of the degree of Dr. Ing., TU Dortmund, p. 238.

Arasli, H., \& Baradarani, S. (2014). European Tourist Perspective on Destination Satisfaction in Jordan's industries. Procedia - Social and Behavioral Sciences, 109, p. 1416 - 1425.

Bakij, A. R. (2002). Amman: A History with Pictures. Greater Amman Municipality Publications, Jordan, p. 214.

Beauregard, R., \& Marpillero-Colomina, A. (2011). More than a Master Plan: Amman 2025. Cities: The International Journal of Urban Policy and Planning, 28(1), p. 62- 69.

Bader, M., Alrousan, R., Abuamoud, I., \& Abualasal, H. (2016). Urban tourism in Jordan: challenges and opportunities case study: Amman. British Journal of Economics, Management \& Trade, 12(4), p. 1- 11.

Belbacha, M.L. (2011). The tourist load capacity within the urban project approach for sustainable tourism: Case of Constantine. Thesis of Magister, University of Constantine, Algeria, p. 250.

Benghadbane, F. (2013). Geography of tourism. Yazouri, Amman, p. 288.

Benghadbane, F. (2001). Satellite cities around Constantine: its transformations, roles and functions. Thesis of Magister, University of Constantine, Algeria, p. 285.

Benidir, F. (2007). Urbanization and urban planning: Case of Constantine, Thesis of doctorate, University of Constantine, Algeria, p. 376.

Benhaddou, Kh.-S. (2017). The practice of tourism marketing in the promotion of the destination of Algeria. Thesis of doctorate, University of Oran 2, Algeria, p. 285.

Bouchareb, A. (2006). Cirta or the urban substratum of Constantine : the region, the city and architecture in antiquity (a study in urban archeology). Thesis of doctorate, University of Constantine, Algeria, p. 604. 
Boudjadja, R. (2014). The environmental dimension in the urban regeneration project of the Bardo district in Constantine. Thesis of Magister, Polytechnic School of Architecture and Urbanism, Algiers, p. 208.

Boufenara, K. (2008). Rehabilitation as a process of the urban project: case of Constantine. Thesis of Magister, University of Constantine, Algeria, p. 241.

Boumendjel, S. (2010). The economic issue of tourism Algerian and socio-economic conditions of sustainable development in Algeria. International Journal of Human Sciences, 7, 1, p. 748- 775.

Boukerzaza, M. (2015). The revaluation of built heritage by the requalification of public spaces, Case of the Medina of Constantine (Algeria) and the eco-district Vauban in Freiburg im Breisgau (Germany). Thesis of doctorate, Jean Monnet University, Saint Etienne, France, p. 560.

Bramwell, B., \& Rawding, L. (1996). Tourism marketing images of industrial cities. Annals of Tourism Research, 23, 1, p. 201-221.

Daher, R. (2008). Amman: Disguised genealogy and recent urban restructuring and neoliberal threats. In Y. Elsheshtawy (Ed.), The evolving Arab city. Tradition, modernity and urban development. Routhedge, London, New York, p. 37- 68.

Dayafla, O. M. (2014). Urban Transportation Networks' Systems in the City of Amman. Dirasat, 41, 3, p. 812-832.

Kadhim, A.M. \& Rajjal, Y., (1988). City Profile: Amman. Cities, 5, p. 318-325.

Hecham-Zehioua, B. (2010). Impacts of projects registered in Constantine and evaluation of its brand image, for an urban project with structuring effect. Thesis of doctorate, University of Constantine, Algeria, p. 395.

Hecham-Zehioua, \& B., Labii, B. (2009). From the structuring effect of the urban project to the prospective analysis of PMMC projects in Constantine. Sciences \& Technologie-D, 29, p. 9-18.

Khawaldah, H. A. (2016). A Prediction of Future Land Use/Land Cover in Amman Area Using GIS Based Markov Model and Remote Sensing. Journal of Geographic Information System, 8, p. 412-427.

Lavergne, M. (1996). Jordan, Karthala, Paris, p. 250.

Lakehal, A. (2013). The plural manufacture of centralities in the periphery of Constantine: the case of the new city Ali Mendjeli. PhD thesis in geography, University François-Rabelais, Tours, France, p. 512.

Larouk, M. H. (1984). Constantine City: A Study in Urban Geography. OPU, Algiers, p. 445.

Michelin, (2003). Road and Tourist Map: Algeria-Jordan: 1/10.00o, Michelin travel edition, Paris.

Milous, I. (2006). The city and sustainable development: Identification and definition of indicators of the sustainability of a city, case of Constantine. Thesis of Magister, University of Constantine, Algeria, p. 358.

Nait-Amar, N. (2015). Housing and living in the shanty towns of Constantine: Conditions and evolutions. Thesis of doctorate, University of Constantine, Algeria, p. 325.

Orieqat, H.M., \& Saymeh, A.F. (2015). Is tourism a gene sector to Jordan's GDP? International Journal of Development and Economic Sustainability, 3 (5), p. $75^{-} 84$.

Pinel, A. (2013). When the South innovates in sustainable matters: the public transport project in Amman. Urban Environment, 7, p. 31- 42.

Potter, R. B., Darmame, K., Barham, N., \& Nortcliff, S. (2009). Ever-growing Amman, Jordan: Urban expansion, social polarisation and contemporary urban planning issues. Habitat International, 33 (1). p. 81-92.

Qian, J., Shen, H., \& Law, R. (2018). Research in sustainable tourism: A longitudinal study of articles between 2008 and 2017. Sustainability, 10, 590, p. 1-13.

Rebai, H. (2010). Impact of urban renewal by structuring modernization projects, case of Constantine. Thesis of Magister, University of Constantine, Algeria, p. 321.

Régis, L. (1880). Constantine: Travel and holidays. Éd. Calmann Lévy, Paris, p. 264.

Sullivan, P. (1999). Globalization: Trade and investment in Egypt, Jordan and Syria since 1980. Arab Studies Quarterly, 21, 3, p. 32-43.

Tessa, A. (1993). Tourism economics and regional planning, OPU, Algiers, p. 234.

Zaidi, I. (2013). The landscape study as a support for the enhancement of landscape heritage in planning policies, the case of the Bardo district in Constantine. Thesis of Magister, University of Annaba, Algeria, p. 198.

Zyoud, Th. (2016). Spatial Planning of Greater Amman Municipality Health Centers Using Geographic Information Systems. Thesis of Magister, University of Jorban, Jorban, p. 133.

**** Directorate of tourism and crafts of the wilaya of Constantine, (2016). Annual Report. Constantine, Algeria, p. 78.

*** Greater Amman Municipality, AFD, WSP, \& Consolidated Consultants, (2010). Transport and Mobility Master Plan for Amman, Final Draft 1, p. 168.

*** Hashemite Kingdom of Jordan, (2016). Jordan in Figures, Amman, Jordan: Department of Statistics, p. 183.

**** ONS: National Office of Statistics, (2011). The urban frame RGPH 2008: The main results of the exhaustive exploitation. National Office of Statistics, Algiers, P. 213.

*** WTO, (2016). International tourism: global perspective, W.T.O., Madrid, p. 56.

*** URBACO-EDR, (2007). Constantine urban coherence plan, Mission II, URBACO, Constantine, p. 231.

www.visitjordan.com

Submitted:

24.11.2018
Revised:

11.02.2019
Accepted and published online 13.02.2019 